\title{
Short storability of Caesalpinia echinata Lam. seeds as a consequence of oxidative processes ${ }^{1}$
}

\author{
Edmir Vicente Lamarca ${ }^{2,3}$ and Claudio José Barbedo ${ }^{2}$
}

Received: 31.07.2012; accepted: 19.11.2012

\begin{abstract}
Short storability of Caesalpinia echinata Lam. seeds as a consequence of oxidative processes). The seed bank is one of the strategies for the preservation of endangered species, such as Caesalpinia echinata Lam. In this work we studied the changes in $\mathrm{O}_{2}$ consumption and $\mathrm{CO}_{2}$ release by seeds incubated at different temperatures and water contents, evaluating the deterioration of seeds through germination and tetrazolium tests. Our results demonstrated that the deterioration processes occurring in $C$. echinata seeds are related to respiration and possibly other oxidative processes, causing the death of embryonic tissues in short periods and loss of seed viability. This characteristic means that seed bank is an alternative for Caesalpinia echinata conservation, however it depends on the control of these oxidative processes.
\end{abstract}

Key words: brazilwood, deterioration, seed respiration, storage

RESUMO - (Baixa capacidade de armazenamento de sementes de Caesalpinia echinata Lam. como consequência de processos oxidativos). O banco de sementes é uma das estratégias para a preservação de espécies ameaçadas de extinção, como Caesalpinia echinata Lam. Neste trabalho foram estudadas mudanças no consumo de $\mathrm{O}_{2}$ e na liberação de $\mathrm{CO}_{2}$ por sementes incubadas em diferentes temperaturas e teores de água, avaliando-se também a deterioração das sementes por meio dos testes de germinação e de tetrazólio. Os resultados demonstraram que os processos de deterioração que ocorrem nas sementes de $C$. echinata estão relacionados com a respiração e possivelmente com outros processos oxidativos, causando em curtos períodos a morte de tecidos embrionários e a perda da viabilidade das sementes. Essas características significam que a utilização do banco de sementes como alternativa para a conservação de Caesalpinia echinata depende do controle desses processos oxidativos.

Palavras-chave: armazenamento, deterioração, pau-brasil, respiração de sementes

\section{Introduction}

Caesalpinia echinata Lam. (brazilwood or pernambuco) is one of the most important plant species in Brazil and is confined to the Brazilian Atlantic rainforest due to its over-exploitation (Rocha et al. 2007, Rocha 2010). The species is now extinct in significant part of its range (Abensperg-Traun 2009) and was included in 2008 in the official list of the Brazilian native species in danger of extinction (Pilatti et al. 2011).

In situ conservation should be the highest priority to conserve species but the ex situ conservation, for example in seed banks, of threatened or endangered plant species has become a necessary and suitable strategy (Godefroid et al. 2010, Khoury et al. 2010, Enßlin et al. 2011), including C. echinata. However, this conservation strategy depends on the longevity of the seeds as well as the knowledge of the physiology of seed deterioration, including biochemical, physiological or genetic degenerative processes.

The period and speed of seed deterioration may be determined primarily by genetic inheritance, initial quality, moisture content and storage conditions (Rajjou $\&$ Debeaujon 2008). Temperature and water content are among the most important storage conditions since they can modify the energetic status of water, affecting the respiratory metabolism, accelerating the deterioration process (Leopold \& Vertucci 1989, Vertucci \& Roos 1990, Kibinza et al. 2006).

1. This work is part of the first Author's Master's Degree Dissertation by Program of Post graduation in Biodiversidade Vegetal e Meio Ambiente, Instituto de Botânica, São Paulo, SP, Brazil

2. Instituto de Botânica, Núcleo de Pesquisa em Sementes, Av. Miguel Stéfano 3687, 04301-012 São Paulo, SP, Brazil

3. Corresponding author: lamarcabio@ig.com.br 
The metabolic reactions differ in their kinetics for each level of hydration of the seed during storage, practically ceasing when almost all water is removed from the cells, for example in the anhydrobiotic organisms (Murdoch \& Ellis 2000, Alpert 2005, Kibinza et al. 2006, Pagnotta \& Bruni 2006). Water, either associated or not with solutes as sugars and proteins, is directly involved with the formation of an intracellular glass matrix, which is essential to reduce or even stop metabolic reactions (Pagnotta \& Bruni 2006). In this so-called glassy state, at water potential below - $150 \mathrm{MPa}$, the oxidative metabolism is limited; however, the protections against free radicals are reduced when the cells hydrate, starting oxidative activity, respiration and the synthesis of both protein and nucleic acids (Vertucci \& Farrant 1995). Water starts producing free radicals and other reactive oxygen species (Voeikov 2006) which, in tissues lacking enzymatic antioxidant agents, can modify cellular components and cause damage (Bernal-Lugo et al. 2000, Møller et al. 2007).

As a matter of fact, it is clear the potential accelerating effect of respiration and other oxidative processes on seed deterioration. However, there is insufficient information in the literature to establish the relationship between respiratory and deterioration rates as well as the interference of the hydration degree and temperature on these processes. The establishment of relations among the energetic state of water, the intensity of temperature and respiration rate as well as seed deterioration can bring substantial contribution to seed conservation and hence, germplasm conservation.

Caesalpinia echinata seeds can be considered as anhydrobiotic organisms as they are desiccationtolerant. However, their germinability remains viable no longer than 3 months at natural environment (ca. $25^{\circ} \mathrm{C}$ ), around 18 months when dried and stored at $7{ }^{\circ} \mathrm{C}$ and for 18 months at $-18^{\circ} \mathrm{C}$ (Barbedo et al. 2002, Hellmann et al. 2006). In order to multiply an endangered species, seed technology shall be developed to provide long term storage in seed banks. The physiological processes involved in rapid loss of viability of $C$. echinata seeds still remain unclear, but they may be related to seed respiration or oxidative reactions such as lipid peroxidation. Therefore, the development of seed technology to allow long term storage in germplasm banks is crucial to the formulation of sound strategies for the conservation of the species.

\section{Material and methods}

Two studies were carried out so as to corroborate our hypothesis that oxidative processes (respiratory or others) are the main cause of rapid deterioration of Caesalpinia echinata Lam. seeds in storage. First, we studied the changes in $\mathrm{O}_{2}$ consumption and $\mathrm{CO}_{2}$ release by seeds incubated at different temperatures and different water contents by analysing both the deterioration of the whole seeds via germination tests as well as cut seeds via tetrazolium test. Secondly, we analysed the changes in the kinetic of the gases consumed/released by seeds with different deterioration rates while incubated at different temperatures and moisture contents, as shown on the results of the first study.

Plant material - Seeds of Caesalpinia echinata were obtained from approximately 20 trees within the Reserva Biológica e Estação Experimental de MogiGuaçu, (22 $\left.{ }^{\circ} 15-16^{\prime} \mathrm{S}, 47^{\circ} 8-12^{\prime} \mathrm{W}\right)$, Brazil. Mature fruits were harvested at pre-dehiscence point (Borges et al. 2005), then each seed was manually removed and immediately dried at laboratory conditions up to ca. $0.10 \mathrm{~g} \mathrm{H}_{2} \mathrm{O} \mathrm{g} \mathrm{g}^{-1}$ dry weight. Then seeds were stored at $7{ }^{\circ} \mathrm{C}$, but no longer than seven days until the beginning of the experiments (Barbedo et al. 2002). These seeds were called high vigour seeds (HVS). Part of HVS were submitted to accelerated aging $\left(42{ }^{\circ} \mathrm{C}, 100 \% \mathrm{RH}\right.$, according to Marcos Filho 1994 and Lamarca et al. 2009) for 12 hours, and then they were called low vigour seeds (LVS). Recent (less than 24 hours) dispersed seeds (RDS) were also collected from the ground. Part of RDS were submittted to the same artificial aging of the HVS, they were then called high deteriorated seeds (HDS).

Seed analyses - The seeds were analysed for water content, water potential (only embryos), germination, respiration rate $\left(\mathrm{O}_{2}\right.$ consumption and $\mathrm{CO}_{2}$ release $)$ and vigour (tetrazolium test). Water content was determined gravimetrically at $103{ }^{\circ} \mathrm{C}$ for 17 hours (Ista 1985) and the results were expressed on $\mathrm{g} \mathrm{H}_{2} \mathrm{O} \mathrm{g}^{-1}$ dry weight. The water potential of the embryo was measured in WP4 potentiometer (Decagon Devices, Pullman, USA) based on the dew point temperature of the air after equilibrium with the sample. The assessment of the potential was performed by sorption isotherms in solutions of polyethylene glycol (PEG $6000)$ at different osmotic potential, based on Michel \& Kaufmann (1973). Germination tests were carried out on germination chambers MA400 (Marconi Ltda, 
Piracicaba, Brazil) at $25^{\circ} \mathrm{C}$ in continuous light (Mello $\&$ Barbedo 2007). Seed germination (primary root protrusion) as well as normal seedling development were recorded daily.

Tetrazolium test was based upon the methodology and the eight categories described by Lamarca et al. (2009). We also estimated the frequency of viable and unviable tissue distribution, corresponding to the percentage of the area occupied by living, dead or damaged tissues for each seed. Thus, we considered the sum of the percentages of each type of tissue identified in all seed treatment. The frequency of tissue distribution was based on the quantification of damaged areas described for soybean and barley (Chauhan 1985).

Incubation of seeds to evaluate respiratory rates Respiratory rates were estimated by packaging the seeds in sealed glass flasks $(600 \mathrm{~mL})$. The caps were punched and the hole $(2 \mathrm{~mm})$ was coated by a rubber septum in which the needles were inserted to collect air samples. The total air volume of the flask was determined hydrostatically. Seed volume was previously determined and then seeds were introduced into the flasks. The closure of the flask determined the beginning of the experiment. Based upon previous experiments of the average daily consumption of $\mathrm{O}_{2}$ and of $\mathrm{CO}_{2}$ release by $C$. echinata seeds, two air samples were collected at 15 and 30 days after the beginning of the experiment. The air samples collected from the flasks were analysed by Illinois analyser 6600 (Illinois Instruments, Inc., Johnsburg, USA), based on a zirconium oxide $\left(\mathrm{ZrO}_{2}\right)$ potentiometric sensor in order to measure the difference of oxygen partial pressure between two electrodes for $\mathrm{O}_{2}$ analysis. For $\mathrm{CO}_{2}$ analysis, an infrared sensor measures the red radiation absorption by $\mathrm{CO}_{2}$. The percentages of the total volume were converted to $\mu \mathrm{mol}$ of $\mathrm{O}_{2}$ or $\mathrm{CO}_{2} \mathrm{~g}$ dry mass $^{-1}$ day $^{-1}\left(\mu \mathrm{mol} \mathrm{g} \mathrm{DM}{ }^{-1} \mathrm{~d}^{-1}\right)$ taking into account the local atmospheric pressure $(0.9 \mathrm{~atm})$, the volume of the air into the flasks, the volume of the seeds, the partial pressure of each gas, the temperature at the time of the readings, the dry mass of seeds (as described above) as well as the total number of days throughout seed incubation.

For the conversion of percentage of $\mathrm{O}_{2}$ and $\mathrm{CO}_{2}$ for $\mu \mathrm{mol}$ initially values obtained in percentage were converted to partial pressure of gas, through equation $\mathrm{p}_{1} / \mathrm{P}=\mathrm{v}_{1} \% / \mathrm{V} \%$ (Feltre 1985), where: $\mathrm{p}_{1}$ : partial pressure of gas (atm), P: local atmospheric pressure $(=0.9 \mathrm{~atm}), \mathrm{v}_{1} \%$ : gas volume $(\%)$ and $\mathrm{V} \%$ : total volume $(=100 \%)$. These values were then converted to $\mu$ mol de $\mathrm{O}_{2}$ e de $\mathrm{CO}_{2}$ through the equation of "Clapeyron", $p_{1} V=n R T$, where: $V$ : total volume of air of flasks (L), n: number of moles of gas, R: universal constant of gas $\left(0.082 \mathrm{~atm} \mathrm{~L} \mathrm{~mol}^{-1} \mathrm{~K}^{-1}\right)$, T: temperature (in Kelvin).

The respiratory quotient $\left(\mathrm{RQ}=\mathrm{CO}_{2}\right.$ released $/ \mathrm{O}_{2}$ consumed) was also calculated as described by Kader $\&$ Saltveit (2002).

Changes in respiration rates as a result of seed moisture and incubation temperature - Samples of HVS were oven-dried at $40{ }^{\circ} \mathrm{C}$ up to $0.06 \mathrm{~g} \mathrm{H}_{2} \mathrm{O} \mathrm{g}{ }^{-1}$ dry weight and hydrated (plastic sandwich boxes, with $100 \% \mathrm{RH}$ at $25^{\circ} \mathrm{C}$ ) in order to obtain seeds with $0.06,0.12,0.18$, 0.25 and $0.32 \mathrm{~g} \mathrm{H}_{2} \mathrm{O} \mathrm{g} \mathrm{g}^{-1}$ dry weight. Immediately after reaching each level the seeds were incubated into the flasks at $25^{\circ} \mathrm{C}$, for respiratory analysis, as described above. For the analyses at different temperatures, HVS were hydrated up to $0.18 \mathrm{~g} \mathrm{H}_{2} \mathrm{O} \mathrm{g}^{-1}$ dry weight, and then incubated into the flasks at 3, 7, 10, 13, 16, 19 and $22{ }^{\circ} \mathrm{C}$. In this experiment, an additional evaluation was performed at 45-day incubation. After the latest assessment of $\mathrm{O}_{2}$ consumption and $\mathrm{CO}_{2}$ release, seeds were evaluated for both water content and water potential. They were also submitted to tetrazolium test.

Changes in respiratory rates by seeds of different deterioration levels - Samples of HVS, LVS, RDS and HDS were hydrated up to $0.11,0.16$ and $0.19 \mathrm{~g}$ $\mathrm{H}_{2} \mathrm{O} \mathrm{g}^{-1}$ dry weight and incubated in the flasks at $13{ }^{\circ} \mathrm{C}$ for 30 days so as to assess $\mathrm{O}_{2}$ consumption and $\mathrm{CO}_{2}$ release. At the end of the incubation period, the seeds were submitted to tetrazolium test and analysed for germination and normal seedling development.

Data analysis - All experiments were based on a complete randomized design, by using three replications. The data were submitted to ANOVA and the means were compared by Tukey test at 5\% probability, using SISVAR 5.3 (Ferreira 2008). All statistical analyses of water potential values (negative values) were performed based upon module data (e.g., with data transformed to positive values).

\section{Results}

Changes in respiratory rates as a result of incubation temperature and moisture content of seeds - Nearly all target water contents were reached, except for $0.32 \mathrm{~g}$ $\mathrm{H}_{2} \mathrm{O} \mathrm{g}^{-1}$ dry weight, which were $0.37 \mathrm{~g} \mathrm{H}_{2} \mathrm{O} \mathrm{g}^{-1}$ dry weight (figure 1a). The increase in water content from 0.06 to $0.37 \mathrm{~g} \mathrm{H}_{2} \mathrm{O} \mathrm{g}^{-1}$ dry weight was accompanied by 
an increase in water potential (figure 1b). However, the initial increases in water content (up to $0.12 \mathrm{~g} \mathrm{H}_{2} \mathrm{O} \mathrm{g}^{-1}$ dry weight) promoted proportionally higher increases in water potential (from -180 MPa to - $40 \mathrm{MPa}$ ) than other hydration levels, indicating a greater change in the energy of water at low hydration levels. At the end of the 30-day incubation, the higher the initial water content of the seeds, the higher the reduction on final water content (figure 1a), probably due to the greater amount of water needed to achieve the hygroscopic equilibrium between the air inside the flasks and the seeds. However, the water potential showed an opposite behaviour, with low decreases among seeds with higher initial water content (figure 1b), except for the lowest moisture content ones $\left(0.06 \mathrm{~g} \mathrm{H}_{2} \mathrm{O} \mathrm{g}^{-1}\right.$ dry weight).

In the first 15 days of incubation, seeds consumed $\mathrm{O}_{2}$ at all hydration levels (figure 1c), but in lower amounts up to $0.25 \mathrm{~g} \mathrm{H}_{2} \mathrm{O} \mathrm{g}^{-1}$ dry weight (below $10 \mu \mathrm{mol} \mathrm{g} \mathrm{DM}^{-1} \mathrm{~d}^{-1}$ ) and substantially higher among seeds with $0.37 \mathrm{~g} \mathrm{H}_{2} \mathrm{O} \mathrm{g}^{-1}$ dry weight (ca. $40 \mu \mathrm{mol} \mathrm{g} \mathrm{DM} \mathrm{g}^{-1} \mathrm{~d}^{-1}$ ). Throughout the following 15 days of incubation, the $\mathrm{O}_{2}$ consumption remained almost the same for the least hydrated seeds; however, this consumption increased at least 2 times more in seeds hydrated up to $0.37 \mathrm{~g} \mathrm{H}_{2} \mathrm{O} \mathrm{g}^{-1}$ dry weight, reaching values close to $90 \mu \mathrm{mol} \mathrm{g} \mathrm{DM}{ }^{-1} \mathrm{~d}^{-1}$. Conversely, the production of $\mathrm{CO}_{2}$ in the first 15 days of incubation (figure 1d), practically non-existent among seeds at lower hydration levels, increased substantially in seeds hydrated up to 0.25 and $0.37 \mathrm{~g} \mathrm{H}_{2} \mathrm{O} \mathrm{g}^{-1}$ dry weight, reaching values close to $30 \mu \mathrm{mol} \mathrm{g} \mathrm{DM}^{-1} \mathrm{~d}^{-1}$. Within the following 15 days of incubation, seeds hydrated up to $0.18 \mathrm{~g} \mathrm{H}_{2} \mathrm{O} \mathrm{g}^{-1}$ dry weight levels continued to release negligible amounts of $\mathrm{CO}_{2}$, however, seeds hydrated up to $0.37 \mathrm{~g} \mathrm{H}_{2} \mathrm{O} \mathrm{g} \mathrm{g}^{-1}$ dry weight released values above $60 \mu \mathrm{mol} \mathrm{g} \mathrm{DM}^{-1} \mathrm{~d}^{-1}$ (figure 1d). By comparing the values in figure $1(\mathrm{c}, \mathrm{d})$, it is clear that $\mathrm{O}_{2}$ consumption was always higher than $\mathrm{CO}_{2}$ release at both 15 or 30 days of incubation, resulting in respiratory quotient much lower than 1.0. Such values suggest that there were other oxidative reactions other than respiration.

Prior to the incubations, seeds showed $73 \%$ germination in which $40 \%$ of them were able to produce normal seedlings. At the end of the 30-day incubation, only the seeds initially with 0.06 and $0.12 \mathrm{~g}$ $\mathrm{H}_{2} \mathrm{O} \mathrm{g}^{-1}$ dry weight maintained some germination (respectively, 53 and 10\%) and only the former retained their ability to produce normal seedlings (20\%). According to Barbedo et al. (2002), this would be actually expected since the incubation resembled the storage at $25^{\circ} \mathrm{C}$ which promotes the total loss of seed viability in less than 90 days, even when seeds have less than $0.10 \mathrm{~g} \mathrm{H}_{2} \mathrm{O} \mathrm{g}^{-1}$ dry weight. However, the reduction to $0.06 \mathrm{~g} \mathrm{H}_{2} \mathrm{O} \mathrm{g}^{-1}$ dry weight preserved some capacity of these seeds to germinate and develop into normal seedlings. Interestingly, the seeds with $0.06 \mathrm{~g}$ $\mathrm{H}_{2} \mathrm{O} \mathrm{g}^{-1}$ dry weight were the ones with the lowest consumption of $\mathrm{O}_{2}$ and $\mathrm{CO}_{2}$ release. However, even these seeds, which are considered suitable for storage due to their supposedly very low metabolic activity, consumed about 3 times more $\mathrm{O}_{2}$ than $\mathrm{CO}_{2}$ release (respectively, 1.0 and $0.3 \mu \mathrm{mol} \mathrm{g} \mathrm{DM}^{-1} \mathrm{~d}^{-1}$ ). This corroborates the hypothesis that oxidation processes are responsible for the rapid deterioration of these seeds.

$\mathrm{O}_{2}$ consumption and $\mathrm{CO}_{2}$ production also changed throughout incubation temperature changes (figure 2a), but no differences were detected among 15, 30 and 45 days of incubation. Changes in seed water content during the period were less than $0.04 \mathrm{~g} \mathrm{H}_{2} \mathrm{O} \mathrm{g}^{-1}$ dry weight. Both $\mathrm{O}_{2}$ consumption and $\mathrm{CO}_{2}$ release increased with rise of temperature, however the rate of this increase was more pronounced in the consumption of $\mathrm{O}_{2}$ (figure 2a). As this was always superior to the release of $\mathrm{CO}_{2}$, once again, the presence of oxidation reactions other than respiration takes place. Furthermore, considering the difference between the rates of increased $\mathrm{O}_{2}$ consumption and $\mathrm{CO}_{2}$ release, these results show that the oxidative reactions are much more intense at higher temperatures, leading to even faster deterioration, whereas under refrigerated conditions, seeds would not be conserved at long-term storage as oxidative processes would still be severe. As a matter of fact, seeds stored at $7{ }^{\circ} \mathrm{C}$ consumed over 4 times more $\mathrm{O}_{2}\left(2.2 \mu \mathrm{mol} \mathrm{g} \mathrm{DM}^{-1} \mathrm{~d}^{-1}\right)$ than the $\mathrm{CO}_{2}$ released $\left(0.5 \mu \mathrm{mol} \mathrm{g} \mathrm{DM}{ }^{-1} \mathrm{~d}^{-1}\right)$ (figure 2a). Even when the temperature approached the freezing point there was still a large consumption of $\mathrm{O}_{2}$ (ca. $0.5 \mu \mathrm{mol} \mathrm{g} \mathrm{DM}^{-1} \mathrm{~d}^{-1}$ ) and practically no release of $\mathrm{CO}_{2}$ (figure 2a). This consumption of $\mathrm{O}_{2}$ for respiration or other oxidation processes caused damages to the seeds and consequently to germination and normal seedling development, as severe as higher the temperature (figure $2 \mathrm{~b}$ ). Just 45 days of incubation at $7{ }^{\circ} \mathrm{C}$ were enough to decrease seed viability to approximately one half of the initial one. Tetrazolium test showed that the higher the temperature, the greater the amount of non-viable tissues in the embryos of C. echinata. (figure 2c). Images of the tetrazolium test showed that the increase of respiration affected 
the integrity of meristematic regions which are essential to maintain seed vigour and viability. The main changes were noted in the radicle, hypocotyl, plumule, at the insertion of the cotyledons and all areas of the cotyledons (figure 2d). Such damages to tissues resulted in progressive damages to the development of normal seedlings (figures $2 b, e$ ) and even for germination (figures $2 b, f$ ) according to the increasing in temperature of incubation, leading to more and more abnormal seedlings (figure $2 \mathrm{~g}$ ) and ending up in almost complete lost of germinability (figure $2 \mathrm{~b}$ ), this one was measured by primary radicle protrusion (figure $2 \mathrm{f}$ ).

Changes in respiratory rates among seeds of different deterioration levels - All seeds (HVS, LVS, RDS and HDS) showed similar behaviour in the kinetics of gases, increasing the respiratory rate as water content increased (figures 3a-d). Also, it can be seen that the oxygen consumption was higher in seeds at $0.19 \mathrm{~g} \mathrm{H}_{2} \mathrm{O} \mathrm{g}^{-1}$ dry weight hydration level and, as occurred at different moisture levels and temperatures described above, $\mathrm{CO}_{2}$ production was always lower than $\mathrm{O}_{2}$ consumption independent of seed deterioration level. The seed respiratory rates into each hydration level, as well as both respiration and other oxidation processes, were higher in vigorous (figure $3 \mathrm{a}$ ) than
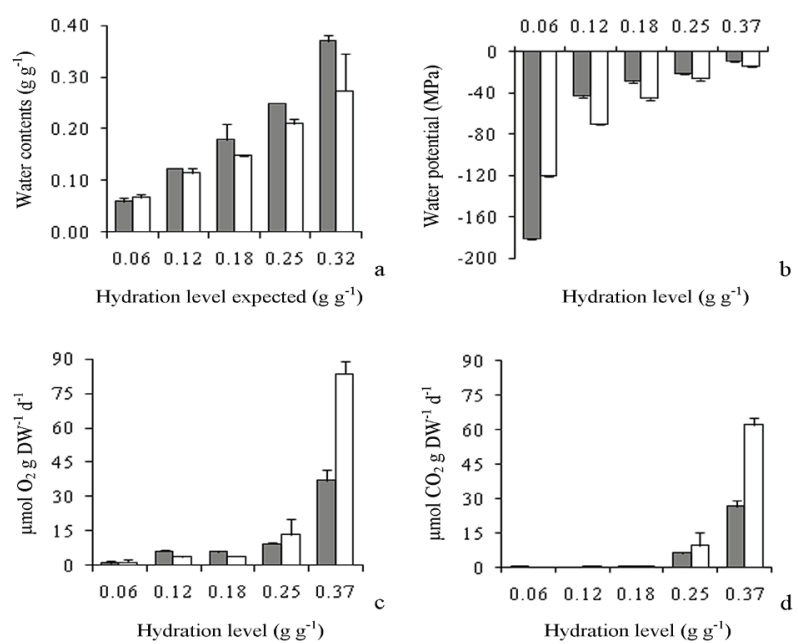

Figure 1. a. Water content in $\mathrm{g} \mathrm{H}_{2} \mathrm{O} \mathrm{g}^{-1}$ dry weight $\left(\mathrm{g} \mathrm{g}^{-1}\right)$, b. Water potential, c. $\mathrm{O}_{2}$ consumption, d. $\mathrm{CO}_{2}$ release by seeds of Caesalpinia echinata Lam. at seven levels of hydration (in $\mathrm{g} \mathrm{H}_{2} \mathrm{O} \mathrm{g}^{-1}$ dry weight, $\mathrm{g} \mathrm{g}^{-1}$ ), incubated by 30 days at $25^{\circ} \mathrm{C}$. Grey columns, in (a) and (b), represent the values before incubation; white columns, after 30 days of incubation. Grey columns, in (c) and (d), represent the values after 15 days of incubation, white columns after 30 days of incubation. Values are means plus standard deviation. in deteriorated (figures 3b-d) seeds. This triggered higher deterioration rates taking into account the initial viability of the tissues in each seed group (figures 3e-h). This loss of embryonic tissue viability reflected directly in the reduction of germination and decline in normal seedling development (table 1). The reduction in respiration rates resulting from seed deterioration might be understood as a result of mitochondrial membranes deterioration and, consequently, the reduction in the energy supply for germination (McDonald 1999 and references therein). It might also represent a decline in the cytochrome pathway activity, as observed among soybean seeds by Amable \& Obendorf (1986). Conversely, these data somewhat contradict the expectation that deteriorated seeds, which were supposed to have lower efficiency of mitochondria activity, should have higher oxidative rates than vigorous seeds. The difference between $\mathrm{O}_{2}$ consumption and $\mathrm{CO}_{2}$ release from vigorous to deteriorated seeds may also result from changes in the detoxification potential present in the seeds that, due to damage accumulation during the incubation period may lose the ability to control the reactive oxygen species (ROS) (Rajjou \& Debeaujon 2008). In this case, the rise of temperature would increase the metabolic activity so that vigorous seeds would depend on the detoxification systems.

\section{Discussion}

Our study clearly demonstrated that the deterioration processes occuring at Caesalpinia echinata seeds are complex and therefore the development of seed storage technology aimed at this species conservation will probably not take place from short - to medium -term. It becomes evident that C. echinata seeds have short life-span under natural conditions. There is also a strong influence of both respiration and other oxidative processes (e.g. ROS activity) which damage seed tissues, affecting seed vigour or even causing viability loss.

Caesalpinia echinata seeds have no dormancy and germinate up to 3 days after shedding (Borges et al. 2005, Mello \& Barbedo 2007). Therefore, this species propagation is likely to happen through nursery grown seedlings rather than seeds. However, even under controlled storage conditions, $C$. echinata dry seeds at refrigeration or even freezing temperatures would be exposed to oxidative processes as well as deterioration in short - to medium - term, as shown in this work. As a matter of fact, Hellmann et al. (2006) demonstrated that it is possible to store C. echinata seeds for at least 
2 years, at freezing temperatures. However, the authors described that even when seeds were stored at -5 or $-18^{\circ} \mathrm{C}$ they started showing signs of deterioration, as shown by some percentage of abnormal seedling development.

The major difference between $\mathrm{O}_{2}$ consumption and $\mathrm{CO}_{2}$ production might be related to the use of fatty acids as initial substrate for respiration. As shown by Mello et al. (2010), lipids in cotyledons of $C$. echinata represent more than 17 percent of DM, whereas linoleic acid represents nearly half of them (more than 45 percent). Respiration using carbohydrates produces respiratory quotient (RQ) close to 1.0 since carbohydrate oxidation (highly oxygenated substrates) involves equal amounts of carbon dioxide and oxygen. On the other hand, the oxidation of fatty acids (poorly oxygenated substrates) produces less $\mathrm{CO}_{2}$ per mole of oxygen and RQ values usually are close to $0.6-0.7$ (Gnaiger \& Kemp 1990, Tcherkez et al. 2003).
However, the low levels of $\mathrm{CO}_{2}$ release in comparison to $\mathrm{O}_{2}$ consumption (figure $2 \mathrm{a}$ and figures 3a-d) mostly resulted in RQ much lower than 0.5 and, in some cases even lower than 0.1 , which indicates non-respiratory reactions. Furthermore, high intakes of $\mathrm{O}_{2}$ could be related to lipid peroxidation and ROS formation, which also reduce $\mathrm{O}_{2}$ (Vertucci \& Leopold 1987, Vertucci 1989, Sacandé et al. 2000, Walters et al. 2002). These oxidative reactions could explain the low viability of $C$. echinata seeds while stored at temperatures higher than the freezing ones, even when they have low water content, as described by Barbedo et al. (2002) and Hellmann et al. (2006). Moreover, great amounts of linoleic acid were found in C. echinata cotyledons, (Mello et al. 2010), which is a polyunsaturated fatty acid (PUFA) and is particularly susceptible to oxidation by singlet oxygen $\left({ }^{1} \mathrm{O}_{2}\right)$ and hydroxyl radical (HO•) (Møller et al. 2007).

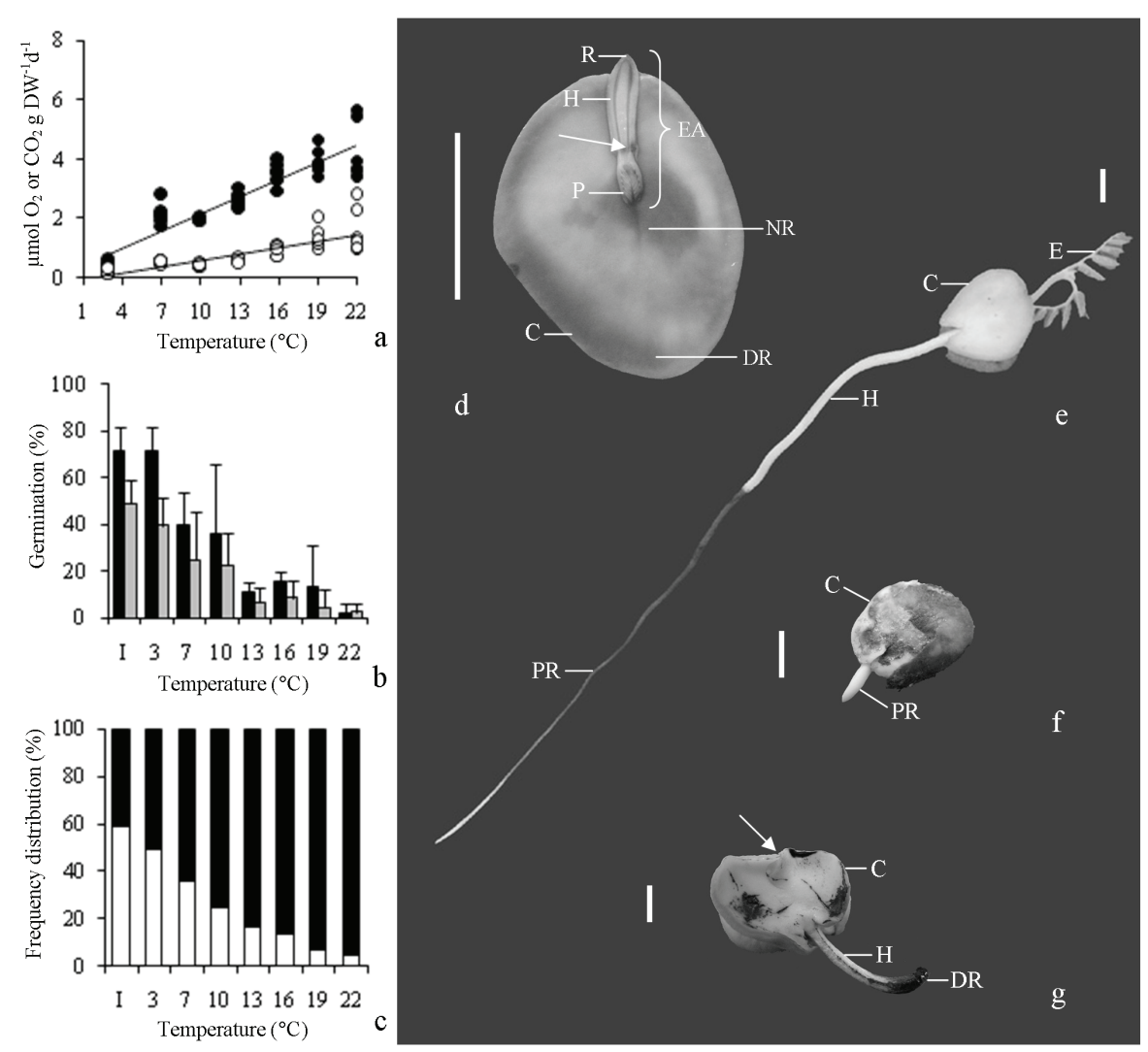

Figure 2. Respiration, germination and deterioration of Caesalpinia echinata Lam. seeds with water content of $0.19 \mathrm{~g} \mathrm{H}_{2} \mathrm{O} \mathrm{g}^{-1} \mathrm{dry}$ weight $\left(\mathrm{g} \mathrm{g}^{-1}\right)$, after 45 days of incubation at different temperatures. a. $\mathrm{O}_{2}$ consumption (closed circle) and $\mathrm{CO}_{2}$ release (open circle): $\mathrm{y}_{\mathrm{O} 2}=0.196 \mathrm{x}+0.196, \mathrm{R}^{2}=0.84 ; \mathrm{y}_{\mathrm{CO} 2}=0.073 \mathrm{x}-0.145, \mathrm{R}^{2}=0.66 . \mathrm{b}$. Germination (black columns) and development of normal seedlings (grey columns). Values are means plus standard deviation. c. Frequency distribution of viable tissue (white columns) and not viable (black columns), obtained by the tetrazolium test. d. Longitudinal section of embryo. EA: embryogenic axis; R: radicle; H: hipocotyl; P: plumule; C: cotyledon; NR: the so-called nearest region; DR: the distal region; Arrow shows the cotyledon insertion region. e. Normal seedling. PR: primary root; H: hipocotyl; C: cotyledon; E: eophylls. f. Germination. PR: protruded primary root; C: cotyledon. g. Abnormal seedling development. DR: dead root; H: hipocotyl; C: cotyledon. Arrow shows the absence of eophylls. Scales: $1 \mathrm{~cm}$. 
Table 1. Germination (\%) and normal seedling development (\%) of Caesalpinia echinata Lam., from seeds at four deterioration levels and three hydration levels (in $\mathrm{g} \mathrm{H}_{2} \mathrm{O} \mathrm{g}^{-1}$ dry weight, $\mathrm{g} \mathrm{g}^{-1}$ ), incubated for 45 days at $13{ }^{\circ} \mathrm{C}$. HVS: high vigour seeds; LVS: low vigour seeds; RDS: recent dispersed seeds; HDS: high deteriorated seeds. Means followed by the same letter (small for columns, capital for lines) are not different by Tukey's test $(p<0.05)$.

\begin{tabular}{ccccc}
\hline \multirow{2}{*}{$\begin{array}{c}\text { Deterioration Levels of } \\
\text { levels }\end{array}$} & $\begin{array}{c}\text { Before } \\
\text { incubation }\end{array}$ & 0.11 & 0.16 & 0.19 \\
\cline { 3 - 5 } & & \multicolumn{3}{c}{ Gydration levels $\left(\mathrm{g} \mathrm{g}^{-1}\right)$} \\
\cline { 3 - 4 } HVS & 71 & $51 \mathrm{aA}$ & $13 \mathrm{aB}$ & $5 \mathrm{aB}$ \\
LVS & 29 & $20 \mathrm{bA}$ & $7 \mathrm{aB}$ & $0 \mathrm{aB}$ \\
RDS & 69 & $13 \mathrm{aB}$ & $5 \mathrm{aB}$ \\
HDS & 20 & $7 \mathrm{bA}$ & $2 \mathrm{aB}$ & $0 \mathrm{aB}$ \\
\hline & & $24 \mathrm{aA}$ & $5 \mathrm{aB}$ & $2 \mathrm{aB}$ \\
HVS & 58 & $5 \mathrm{cA}$ & $0 \mathrm{aA}$ & $0 \mathrm{aA}$ \\
LVS & 24 & $15 \mathrm{bA}$ & $7 \mathrm{aB}$ & $0 \mathrm{aC}$ \\
RDS & 62 & $0 \mathrm{cA}$ & $0 \mathrm{aA}$ & $0 \mathrm{aA}$ \\
\hline HDS & 9 & & &
\end{tabular}

Our results provide evidence on the damage caused by oxidative reactions as revealed by tetrazolium tests performed on seeds based upon different hydration treatments as well as different temperatures. In this work, the target levels of controlled seed hydration covered two energetic states of water (Vertucci \& Farrant 1995). Seeds containing only Type I water released low amounts of $\mathrm{CO}_{2}$; however, at this hydration level the protection system against free radicals decreased, as evidenced by the high consumption of $\mathrm{O}_{2}$. A greater hydration level reached on Type II water increased oxidation, and probably resulted in degradation of cell components, extending the damage to the embryonic tissues. Instead, the temperature clearly interfered with the rapid deterioration of $C$. echinata seeds. Incubation of seeds at temperatures above freezing conditions generated the development of bright red by the tetrazolium test, indicating an intense process of tissue damage, especially in meristematic regions, such as radicle, plumule and cotyledons insertion (figure 2d) as these regions are considered essential for maintaining seed viability and vigour, which are aimed at seed conservation. Seed storage at its basal temperature for germination, as suggested by Pritchard et al. (1995) for the storage of Araucaria hunteinii K. Schum, could be appropriate to reduce the deterioration rate of $C$. echinata seeds, but not for conservation. As shown by Mello \& Barbedo (2007), the basal temperature for the germination of these seeds would range between 10 and $14{ }^{\circ} \mathrm{C}$ which would cause severe damage to their physiological quality. Photooxidation process shall be considered in the deterioration of $C$. echinata seeds in the same way as Salix nigra March. has been accounted for (Roqueiro et al. 2010). Both species have desiccation tolerant seeds. However, both S. nigra and C. echinata differ from typical orthodox seeds because they lose viability in few weeks at room temperatures. Roqueiro et al. (2010) found that $S$. nigra seeds were very susceptible to photooxidation since there were large decreases in galactolipids which are contiguous in thylakoid membrane structure. Therefore, light and oxygen may promote strong photooxidation processes mediated by free radicals (FR) and ROS.

Interestingly, $C$. echinata seeds, which were manually harvested directly from fruits and stored immediatelly after collection showed longer storability in comparison to seeds exposed to longer periods of light prior to their storage (Barbedo et al. 2002). Roqueiro et al. (2010) described that the embryonic tissues of $S$. nigra most damaged by FR were those of the abaxial side of the cotyledons and the most-external tissues of the axis and root tips. Therefore, the damage caused to seeds was evidenced by abnormal development in the roots and cotyledons, reducing the normal seedling development to zero level. This behaviour was also observed in our results, mainly at low temperatures. The low percentages of normal seedling development and the progressive germinability loss of $C$. echinata seeds, associated with the high amount of lipids (mainly linoleic acid) 
as well as the great difference between $\mathrm{O}_{2}$ consumption and $\mathrm{CO}_{2}$ release, suggest that FR and ROS could be the most important factors leading to rapid seed deterioration. Furthermore, these seeds probably have insufficient amount of antioxidants which could reduce the damaging effects of ROS and FR, as tocopherols that are lipophilic antioxidants abundant in seeds of several species and are related to longevity (Sattler et al. 2004). Sucrosyl oligosaccharides (SOS) might detoxify ROS in chloroplasts and vacuoles and could act sinergistically with phenolic compounds
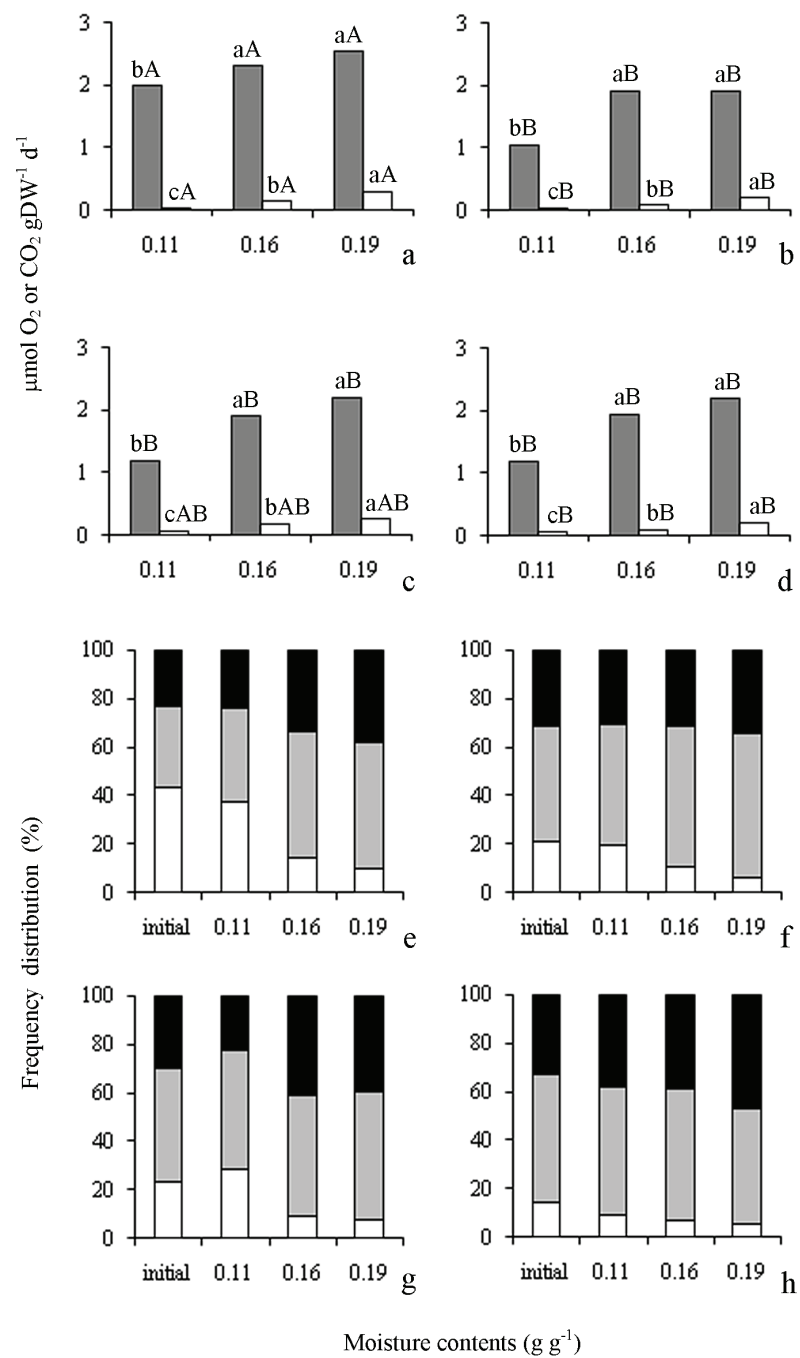

Figure 3. Seeds of Caesalpinia echinata Lam. with different initial levels of hydration (in $\mathrm{g} \mathrm{H}_{2} \mathrm{O} \mathrm{g}^{-1}$ dry weight, $\mathrm{g} \mathrm{g}^{-1}$ ), incubated for 45 days at $13{ }^{\circ} \mathrm{C}$. a-d. $\mathrm{O}_{2}$ consumption (grey columns) and $\mathrm{CO}_{2}$ release (white columns). e-h. Frequency distribution of viable (white), deteriorated (grey) and dead (black) tissues, obtained by the tetrazolium test. a and e: high-vigour seeds; $b$ and f: low-vigour seeds; $c$ and g: recent dispersed seeds; $d$ and $h$ : high deteriorated seeds. Means followed by the same letter (small, comparing water content, capital, comparing deterioration levels) are not different by Tukey's test $(p<0.05)$. as integrated redox system, quenching ROS and contributing to stress tolerance (Van den Ende \& Valluru 2008). This could explain the reduction in stachyose levels of C. echinata seeds, greater for seeds stored at room temperature than seeds stored at cold temperatures (Garcia et al. 2006). However, the low initial levels of SOS in C. echinata seeds would not be enough for longer effects against FR and ROS. The conservation of $C$. echinata seeds remains a challenge and the effective conservation of this endangered species shall require incentive-driven preservation strategies. Therefore, in situ conservation is crucial for this species because apart from the difficulty in seed conservation, there are few remaining trees capable of producing seeds (therefore, the replacement of seed bank could be difficult), seed dispersal often coincides with less favorable periods to obtain high quality seeds (therefore, seed longevity could be very low) and the period in which the seeds are mature to be collected is summarized in a few days. Our results showed that free radical and reactive oxygen species production seem to be the main cause of tissue damage in Caesalpinia echinata seeds and, consequently, the main cause of its short storability.

\section{Acknowledgements}

The authors wish to thank O. Vieira for language help and Instituto de Botânica for allowing us to harvest the seeds. Financial support for this work from the CNPq (Proc. 481484/2007-8, 477640/2009-5 and 306537/2010-9) and FAPESP (2005/04139-7) is gratefully acknowledged. Thanks are also due to CAPES for scholarship (Master's Degree) to the first Author and Programa de Pós-Graduação em Biodiversidade Vegetal e Meio Ambiente IBt/ SMA, for the post graduation course. C.J. Barbedo is associated researcher of $\mathrm{CNPq}$.

\section{Literature cited}

Abensperg-Traun, M. 2009. CITES, sustainable use of wild species and incentive-driven conservation in developing countries, with an emphasis on southern Africa. Biological Conservation 142: 948-963.

Alpert, P. 2005. The limits and frontiers of desiccationtolerant life. Integrative and Comparative Biology 45: 685-695.

Amable, R.A. \& Obendorf, R.L. 1986. Soybean seed respiration during simulated preharvest deterioration. Journal of Experimental Botany_182: 1364-1375. 
Barbedo, C.J., Bilia, D.A.C. \& Figueiredo-Ribeiro, R.C.L. 2002. Tolerância à dessecação e armazenamento de sementes de Caesalpinia echinata Lam. (pau-brasil), espécie da Mata Atlântica. Revista Brasileira de Botânica 25: 431-439.

Bernal-Lugo, I., Camacho, A \& Carballo, A. 2000. Effects of seed ageing on the enzimic antioxidant system of maize cultivars. In: M. Black, K.J. Bradford \& J. Vázquez-Ramos (eds.). Seed biology: advances and applications. CABI Publishing, Wallingford, pp. 151-160.

Borges, I.F., Del Giudice Neto, J., Bilia, D.A.C., Figueiredo-Ribeiro, R.C.L. \& Barbedo, C.J. 2005. Maturation of seeds of Caesalpinia echinata Lam. (brazilwood), an endangered leguminous tree from the Brazilian Atlantic Forest. Brazilian Archives of Biology and Technology 48: 851-861.

Chauhan, K.P.S. 1985. The incidence of deterioration and its localisation in aged seeds of soybean and barley. Seed Science and Technology 13: 769-773.

Enßlin, A., Sandner, T.M. \& Matthies, D. 2011. Consequences of ex situ cultivation of plants: genetic diversity, fitness and adaptation of the monocarpic Cynoglossum officinale L. in botanic gardens. Biological Conservation 144: 272-278.

Feltre, R. 1982. Química geral. 2 ed. Moderna, São Paulo.

Ferreira, D.F. 2008. SISVAR: um programa para análises e ensino de estatística. Revista Symposium 6: 36-41.

Garcia, I.S., Souza, A., Barbedo, C.J., Dietrich, S.M.C. \& Figueiredo-Ribeiro, R.C.L. 2006. Changes in soluble carbohydrates during storage of Caesalpinia echinata Lam. (brazilwood) seeds, an endangered leguminous tree from the brazilian atlantic forest. Brazilian Journal of Biology 66: 739-745.

Gnaiger, E. \& Kemp, R.B. 1990. Anaerobic metabolism in aerobic mammalian cells: information from the ratio of calorimetric heat flux and respirometric oxygen flux. Biochimica et Biophysica Acta 1016: 328-332.

Godefroid, S., Van de Vyer, A. \& Vanderborght, T. 2010. Germination capacity and viability of threatened species collections in seed banks. Biodiversity and Conservation 19: 1365-1383.

Hellmann, M.E., Mello, J.I.O., Figueiredo-Ribeiro, R.C.L. \& Barbedo, C.J. 2006. Tolerância ao congelamento de sementes de pau-brasil (Caesalpinia echinata Lam.) influenciada pelo teor de água. Revista Brasileira de Botânica 29: 91-99.

Ista. 1985. International rules for seed testing. Seed Science and Technology 13(Suppl.): 356-513.

Kader, A.A. \& Saltveit, M.E. 2002. Respiration and gas exchange. In: J.A. Bartz, J.K. Brecht \& J, Weichmann (eds.). Postharvest physiology and pathology of vegetables. Marcel Deckker, New York, pp. 7-29.

Khoury, C., Laliberté, B. \& Guarino, L. 2010. Trends in ex situ conservation of plant genetic resources: a review of global crop and regional conservation strategies. Genetic Resources and Crop Evolution 57: 625-639.
Kibinza, S., Vinel, D., Côme, D., Bailly, C. \& Corbineau, F. 2006. Sunflower seed deterioration as related to moisture content during ageing, energy metabolism and active oxygen. Physiologia Plantarum 128: 496-506.

Lamarca, E.V., Leduc, S.N.M. \& Barbedo, C.J. 2009. Viabilidade e vigor de sementes de Caesalpinia echinata Lam. (pau-brasil - Leguminosae) pelo teste de tetrazólio. Revista Brasileira de Botânica 32: 793-803.

Leopold, A.C. \& Vertucci, C.W. 1989. Moisture as a regulator of physiological reactionin seeds, In: P.C. Stanwood \& M.B. McDonald (eds.). Seed Moisture. Crop Science Society of America, Madison, pp. 51-67.

Marcos Filho, J. 1994. Teste de envelhecimento acelerado. In: R.D. Vieira \& N.M. Carvalho (eds.). Testes de vigor em sementes. FUNEP, Jaboticabal, pp.133-149.

McDonald, M.B. 1999. Seed deterioration: physiology, repair and assessment. Seed Science and Technology 27: 177-237.

Mello, J.I.O. \& Barbedo, C.J. 2007. Temperatura, luz e substrato para a germinação de sementes de pau-brasil Caesalpinia echinata Lam., LeguminosaeCaesalpiniodeae. Revista Árvore 31: 645-655.

Mello, J.I.O., Barbedo, C.J., Salatino, A. \& FigueiredoRibeiro, R.C.L. 2010. Reserve carbohydrates and lipids from the seeds of four tropical tree species with diferent sensitivity to desiccation. Brazilian Archives of Biology and Technology 53: 889-899.

Michel, B.E. \& Kaufmann, M.R. 1973. The osmotic potential of polyethylene glycol 6000. Plant Physiology 51: 914-916.

Møller, I.M., Jensen, P.E. \& Hansson, A. 2007. Oxidative modifications to cellular components in plants. Annual Review of Plant Physiology 58: 459-481.

Murdoch, A.J. \& Ellis, E.H. 2000. Dormancy, viability and longevity. In: M. Fenner (ed.). Seeds: the ecology of regeneration in plant communities. 2 ed. CABI Publishing, Wallingford, pp. 183-214.

Pagnotta, S.E. \& Bruni, F. 2006. The glassy state of water: a 'stop and go' device for biological processes. In: G.H. Pollack, I.L. Cameron \& D.N. Wheatley (eds.). Water and the cell. Springer, Dordrecht, pp. 93-112.

Pilatti, F.K., Aguiar, T., Simões, T., Benson, E.E. \& Viana, A.M. 2011. In vitro and cryogenic preservation of plant biodiversity in Brazil. In Vitro Cellular \& Developmental Biology-Plant 47: 82-98.

Pritchard, H.W., Tompsett, P.B., Manger, K. \& Smidt, W.J. 1995. The effect of moisture content on the low temperature responses of Araucaria hunsteinii seed and embryos. Annals of Botany 76: 79-88.

Raujjou, L. \& Debeaujon, I. 2008. Seed longevity: survival and maintenance of high germination ability of dry seeds. Comptes Rendus Biologies 331: 796-805. 
Rocha, Y.T. 2010. Distribuição geográfica e época de florescimento do pau-brasil (Caesalpinia echinata Lam. - Leguminosae). Revista do Departamento de Geografia 20: 23-36.

Rocha, Y.T., Presotto, A. \& Cavalheiro, F. 2007. The representation of Caesalpinia echinata (Brazilwood) in Sixteenth-and-Seventeenth-Century Maps. Anais da Academia Brasileira de Ciências 79: 751-765.

Roqueiro, G., Facorro, G.B., Huarte, M.G., Celis, E.R., García, F., Maldonado, S. \& Maroder, H. 2010. Effects of photooxidation on membrane integrity in Salix nigra seeds. Annals of Botany 105: 1027-1034.

Sacandé, M., Hoesktra, F.A., Van Aelst, A.C. \& Ric De Vos, C.H. 2000. Is oxidative stress involved in the loss of neem (Azadirachta indica) seed viability. Seed Science Research 10: 381-392.

Sattler, S.E., Gilliland, L.U., Magallanes-Lundback, M., Pollard, M. \& DellaPenna, D. 2004. Vitamin $\mathrm{E}$ is essential for seed longevity and for preventing lipid peroxidation during germination. The Plant Cell 16: 1419-1432.

Tcherkez, G., Nogués, S., Bleton, J., Cornic, G., Badeck, F. \& Ghashghaie, J. 2003. Metabolic origin of carbon isotope composition of leaf dark-respired $\mathrm{CO}_{2}$ in french bean. Plant Physiology 131: 237-244.
Van den Ende, W. \& Valluru, R. 2008. Sucrose, sucrosyl olligosaccharides, and oxidative stress: scavenging and salvaging? Journal of Experimental Botany 60: 9-18.

Vertucci, C.W. \& Farrant, J.M. 1995. Acquisition and loss of desiccation tolerance. In: J. Kigel \& G. Galili (eds.). Seed development and germination. Marcel Dekker, New York, pp. 237-271.

Vertucci, C.W. \& Leopold, A.C. 1987. Water Binding in Legume Seeds. Plant Physiology 85: 224-231.

Vertucci, C.W. \& Ross, E.E. 1990. Theoretical basis of protocols for seed storage. Plant Physiology 94: 1019-1023.

Vertucci, C.W. 1989. The effects of low water contents on physiological activities of seeds. Physiologia Plantarum 77: 172-176.

Voeikov, V.2006. Biological significance of active oxygendependent processes in aqueous systems. In: G.H. Pollack, I.L. Cameron \& D.N. Wheatley (eds.). Water and the cell. Springer, Dordrecht, pp. 285-298.

Walters, C., Farrant, J.M., Pammenter, N.W. \& Berjak, P. 2002. Desiccation stress and damage. In: M. Black \& H.W. Pritchard (eds.). Desiccation and survival in plants: drying without dying. CABI Publishing, Wallingford, pp. 263-291. 